\title{
FROM BID TIME RETURN TO SOMEWHERE IN TIME: MATHESON AS ADAPTER, ADAPTATION AS TRANSFORMATION, AND THE PERKS OF INFIDELITY
}

\author{
Ben KoOYMan \\ University of South Australia \\ Ben.Kooyman@unisa.edu.au
}

Recibido: 15-12-2013

Aceptado: 16-04-2014

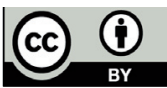

RESUMEN

Este ensayo examina la adaptación cinematográfica de la novela de ciencia ficción Bid Time Return (1975) de Richard Matheson. La película se titula Somewhere in Time (1980), con guión de Matheson, dirigida por Jeannot Szwarc y protagonizada por Christopher Reeve y Jane Seymour. Si bien Bid Time Return obtuvo el World Fantasy Award, muchos de los lectores de Matheson, como el mismo autor ha indicado, pensaron que no era su mejor obra, y ni la novela ni su adaptación cinematográfica tuvieron éxito comercial. Sin embargo, tanto el texto literario como la película cuentan con seguidores fieles. Somewhere in Time incluso ha generado su propio club de fans: la International Network of Somewhere in Time Enthusiasts. Además esta película es digna de atención como transformación crítica del texto original.

Palabras clave: Richard Matheson, Bid Time Return, Somewhere in Time, adaptación.

ABSTRACT

This essay closely examines the adaptation of Richard Matheson's science-fiction romance novel Bid Time Return (1975) into the film Somewhere in Time (1980), scripted by Matheson, directed by Jeannot Szwarc, and starring Christopher Reeve and Jane Seymour in the lead roles. Whilst Bid Time Return was awarded the World Fantasy Award, many of Matheson's loyal readers, as the author has noted, found the novel «soft», and neither it nor its film adaptation were commercially successful. However, both novel and film have developed loyal followings, with Somewhere in Time even spawning its own fan club, the International Network of Somewhere in Time Enthu- 
siasts. In addition, the film is noteworthy as a critical transformation of its own source text.

KeYwords: Richard Matheson, Bid Time Return, Somewhere in Time, Adaptation

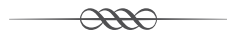

The intentions of this essay are twofold. Firstly, through close comparison of novel and film side by side, this essay illustrates how Matheson has translated his story to screen, tailoring it to the strengths and assets of the film medium. ${ }^{1}$ Matthew R. Bradley (2010: 7) dubs Matheson «[...] one of the most prolific screenwriters to come from a literary background... able to bring his own work to the screen with an unusual frequency.» Few authors have been as well-suited to adapting their own source texts to film and television as Matheson: his prolific work as both original screenwriter and adapter of source material, both his own and others, clearly gave him insight into the distinct strengths of each medium, how to tweak texts from one medium to the next, and how to translate the narrative incidents and spirit of a text while changing or jettisoning attributes that are not so easily transferable. ${ }^{2}$ Some-

1 Because Matheson's screenplay for Somewhere in Time is not readily available in complete form - the script is available online (see Matheson, 1980b), but that document contains only about $75 \%$ of the finished screenplay, with segments of the script essential to my analysis not included - I have elected to use the finished film as my point of comparison to Matheson's novel rather than this incomplete version of the script. While I recognise that film authorship is collaborative and multi-faceted, and do not wish to perpetuate Matheson as sole auteur of Somewhere in Time, I believe this close equation of script with finished product is justified in two key respects: the finished film is a very faithful translation of the aforementioned script to screen, and Matheson was closely involved with the production of the film, noting it was «[...] the only time I had ever been asked» to attend production (qtd. in Bradley, 2010: 221). Having said that, since my point of reference is the finished film I will, where relevant, extend my discussion to consider Szwarc's cinematic translation of the text, John Barry's musical score, the actors' performances, and so on.

2 Among the most notable adaptations of his own work that Matheson helped steer to the screen - whether as sole or contributing screenwriter - are The Incredible Shrinking Man (1957, his screenwriting debut based on The Shrinking Man, 1956), The Last Man on Earth (1964, based on I Am Legend, 1954), The Legend of Hell House (1973, based on Hell House, 1971), and two versions of his short story «Nightmare at 20,000 Feet» (1961). These two short story adaptations, for television and film respectively, provide an illuminating case study of Matheson's savvy as adapter of his own work. The short story is driven by the neurotic thought processes of protagonist Bob Wilson as he is taunted by a gremlin outside his aeroplane window. For its 1963 adaptation for television as an episode of The Twilight Zone, helmed by Richard Donner, Matheson gives the story's protagonist a travelling companion to help manage the flow of information and exposition. In its subsequent adaptation for Twilight Zone: The Movie (1983), this exposition is trimmed and the segment is tailored to the more aggressively cinematic and visceral approach of director George Miller. Each new version of the story further reduces the interiority and ex- 
where in Time is testament to this skill set, and this essay builds upon works like Bradley's in promoting interest in and scholarship on Matheson as screenwriter.

Secondly, through close analysis of the film's most significant deviation from its source text, namely its denouement, this essay characterises Somewhere in Time as a critical «transformation» - to borrow a term increasingly employed in adaptation studies (e.g. Frus \& Williams, 2010; Stam, 2005a) - of its literary precursor. While superficially a faithful adaptation of Matheson's romantic weepie, this fundamental difference between book and film marks Somewhere in Time as a tonal and ideological re-interpretation of its source. In illuminating and endorsing this transformation, this essay joins the chorus of adaptation scholars and commentators from the past decade (e.g. Hutcheon, 2006; Kooyman, 2013; Leitch, 2008; MacFarlane, 2007; Sanders, 2006) who have argued that fidelity cease being the lynchpin of discourse surrounding adaptation, and posits Somewhere in Time as an exemplary case of Robert Stam's belief that «The shift from a single-track verbal medium such as the novel to a multi-track medium like film, which can play not only with words (written and spoken) but also with music, sound effects, and moving photographic images, explains the unlikelihood, and I would suggest even the undesirability, of literal fidelity» (Stam, 2005b: 4).

\section{PRESENT}

Bid Time Return is framed by Matheson as a posthumously published manuscript, written by narrator Richard Collier as a record of his journey through time. This manuscript is preceded by an opening note (and bookended with a postscript) by Collier's surviving brother Robert, who inherited and chose to publish the document. ${ }^{3}$ Due to the inclusion of this opening note, readers of Bid Time Return know from the outset that the narrator of the work is deceased, which casts a shadow of inevitable tragedy over the book. Moreover, Robert's opening remarks generate ambivalence about the authenticity of the manuscript that follows, though he contends that «[t]o Richard, this was not a work of fiction» (Matheson, 1980a: 11-12).

position of the source material for their increasingly visual mediums, whilst preserving the story's sense of escalating dread and paranoia.

3 This is not Matheson's only novel to use such a framing device: his subsequent novel, What Dreams May Come (1978), employs a similar conceit. That book is narrated, or more precisely dictated, from beyond the grave by its author Chris Nielsen, who recounts his otherworldly exploits. A psychic records Nielsen's narration and delivers the manuscript to Chris's brother, also named Robert, who likewise tends to its publication. 
The novel proper begins in diary format in November 1971. Collier is on a road trip from Los Angeles to San Diego, his destination decided via coin toss. The journey is recounted in short, sharp snippets of prose, some dictated into a cassette recorder, predominantly in present tense but with occasional passages of past tense. Though the first few pages mainly record Collier's impressions of his journey, we also learn he is a television writer in his $30 \mathrm{~s}$ with a brain tumour and a short time to live. He also confesses «I never met a woman I could love» (Matheson, 1980a: 16), establishing his initial emotional aloofness. This soon changes when Collier winds up at Hotel de Coronado, where he discovers «[...] the most gloriously lovely face I've ever seen in my life» (37). He is referring to a 75-year old photograph of stage actress Elise McKenna, which he discovers when perusing an exhibit at the hotel. He becomes enthralled with this picture, and in the pages that follow the brittle, glib tone of the book's earlier shotgun narration shifts into longer passages marked by an increasingly haunted, obsessive tone.

Collier conducts research on McKenna and chronicles his findings in detail, recounting her career and life as well as his own evolving impressions of her. He is struck by a number of contradictions as well as coincidences, including their shared affinity for Mahler (which becomes Rachmaninoff in the film) and the fact they once attended the same party. ${ }^{4}$ As a novelist and short story writer, one of Matheson's greatest assets is his ability to illuminate the interior life of his characters, and here he paints a vivid portrait of Collier's intellectual cogs and screws turning as he processes this information. This is accentuated by the fact that Collier himself is a writer narrating his actions and impressions; hence the prose is invested with additional flair for phrasing. Collier then investigates time travel. Annotations by Robert indicate that large chunks of theory and text have been eliminated from this section of the manuscript, but the theoretical information relating specifically to Collier's impending journey remains. Following this research, Collier embarks on his journey, removing the accoutrements and trappings of the present and willing himself through self-hypnosis and deep contemplation to November 1896.

At this point it is worth turning to Somewhere in Time to discuss how the narrative incidents recounted thus far are translated to screen. Perhaps the biggest challenge for any adapter of Bid Time Return would be finding cinematic equivalence for the interiority of the book's narration. This challenge is by no means unique to Bid Time Return. Linda Hutcheon (2006: 56) notes,

4 Rachmaninoff's music also features prominently in Brief Encounter (1945), another romantic classic. 
though does not endorse, the cliché that «[...] literary fiction, with its visualising, conceptualising, and intellectualised apprehension, "does" interiority best; the performing arts, with their physical immersion, are more suited to representing exteriority.» Or, as Pauline Kael more succinctly puts it, «[m]ovies are good at action; they're not good at reflective thought or conceptual thinking» (qtd. in Hutcheon, 2006: 57). Many film adaptations of novels or short stories have had to grapple with this fundamental (if reductive) difference between mediums. Yet it poses a particular challenge for adapters of Matheson's published work, including Matheson himself. One of his literary specialties is crafting everyman characters pushed to their wit's end - or «[...] individual[s] isolated in a threatening world, attempting to survive», as Matheson himself describes it (qtd. in Bradley, 2010: 6) - and, as indicated earlier, illuminating their inner life. Stephen King (1981: 322), one of the author's most notable admirers, asserts that «[p] erhaps above all else, Matheson excels at the depiction of one man alone, locked in a desperate struggle against a force bigger than himself.» King is talking specifically about Matheson's novel The Shrinking Man (1956) and its protagonist Scott Carey's adversarial relationship with a predatory spider, yet he could easily be talking about Richard Collier falling for a woman from a bygone era, embarking on an impossible journey to meet her, and skirting repeatedly with failure. ${ }^{5}$ Whether writing in first person (Bid Time Return) or third person (The Shrinking Man), Matheson furnishes his characters with vivid interior monologues and showcases their thought processes, anxieties, and neuroses in detail. This quality, as well as the everyman vintage of his characters - which makes their unravelling on the page so compelling - has proven difficult to translate to film. In adapting Bid Time Return for film, Matheson finds a satisfactory middle ground between the interiority of his novel and the expected exteriority of the film medium. Much of this is accomplished through shifting the novel's focus on telling the reader - sometimes to the point of grating - to showing the audience. Collier no longer narrates his story in first person, but rather we watch it unfold in standard cinematic third person. Exposition is trimmed and actions function in place of explanations.

Another strategy is recalibrating the narrative so that viewers are not attached solely to Collier for the duration of the story. He remains the focal

5 He could also just as easily be talking about Robert Neville's quest to survive a world populated by vampires in I Am Legend, David Cooper's struggle with the sex-crazed spirit who possesses his wife in Earthbound (1982), the taunted Bob Wilson of «Nightmare at 20,000 Feet» and any number of desperate, neurotic Matheson protagonists. 
point for the film's majority, but is not present in every moment as he is in the novel. This shift in focus is signalled in the opening scene, an invention for the film, where we meet the senior McKenna in the present. The film's Collier is a playwright, and the story opens with the debut performance of his first play Too Much Spring. Collier is toasting his success at the after-party when an elderly woman, who we later discover is McKenna, approaches him through the crowd, presses a pocket watch into his hand, and urges him to «[c]ome back to me.» She leaves the party, returns to her room at the Grand Hotel in Michigan (replacing the novel's Hotel de Coronado), listens to Rachmaninoff, and later that evening (as we discover later) dies. In addition to providing an intriguing entry point into the story, this scene also provides the character of McKenna with a greater level of agency: she is not merely the passive object of Collier's visit to the past, but is instrumental in facilitating his visit.

The film segues from McKenna listening to Rachmaninoff on her final evening to Richard listening to the same music in his apartment eight years later. He is now an established playwright in Chicago, a profession which aligns him more closely with that of his future love than the novel's television writer. He does not have a terminal brain tumour like his literary counterpart, but he is grappling with writer's block and mourning a recent break-up. His frustration and apathy are palpable and are conveyed through actor Reeve's curt tone and body language in place of the novel's brittle prose. On impulse he decides to take a road trip and winds up at the Grand Hotel.

The narrative incidents which follow are similar to those in Matheson's novel, albeit tweaked by the author-screenwriter and filmmakers for cinematic effect. Collier discovers McKenna's photograph in the hotel's exhibit, illuminated by a shaft of light for dramatic effect and accompanied by John Barry's lush musical score. Like his literary counterpart, Collier is instantly entranced. His enchantment and obsession are depicted without dialogue or narration, through short scenes of him contemplating McKenna at dinner, unable to sleep, and returning to look at her picture in the middle of the night. As he does in the novel, Collier visits town to research McKenna, and voiceover is used here to convey key points of his research. However, where in the novel Collier learns everything he knows about McKenna and time travel through reading, in the film two new characters have been created to orally convey some of that information to both Collier and the audience: Laura Roberts, a friend of McKenna, provides further information about her, and Gerald Finney, one of his former college professors, tells him about time travel. The incidents leading up to Collier's journey through time are also similar to the 
novel: he purchases an old suit, secures old money, removes all accoutrements of the present day from his hotel room, and encounters setbacks and frustration and eventually success as he struggles to will himself back in time.

Director Szwarc consciously opted not to use special effects to depict Collier's journey through time (Bouzereau, 2000), despite working in the era of such special effects and fantasy-driven juggernauts as Star Wars (1977), Close Encounters of the Third Kind (1977), Star Trek: The Motion Picture (1979), and the Reeve-starring Superman (1978). Instead, his journey is depicted through subtle adjustments to light and sound to keep it «[...] simple and pure» (Szwarc, 2000), and the film subsequently uses Fuji stock for its period scenes to differentiate them from scenes set in the present and filmed on Kodak (Bradley, 2010: 223). Szwarc's emphasis on purity is of some importance to the film's overall conception, and will be returned to later.

PAST

As indicated previously, the first section of Bid Time Return unfolds in a diary-type format, with Collier typing or dictating onto cassette his impressions and experiences. These observations and recollections start out short, sharp and brittle, gradually becoming longer as his obsession for and research into McKenna deepens. Once the novel shifts to 1896, this format changes. The passages of prose constituting this section of the book are all considerably longer, and from this point Bid Time Return adopts a more traditionally novelistic style. This is explained by the fact that Collier has fewer chances to record his recollections and must do so in long stretches of writing. The novel also switches from its mingling of present and past tense in the modern section to predominantly past tense in the period section, which is fitting given that these passages of text are written in retrospective bouts. The switch to past tense also thematically complements the fact that Collier is, indeed, in the past. The overall effect of this, along with the more expansive prose, is that the writing style becomes more fitting to the literary period of the novel's action (late 1800s). It also mirrors the intensification of Collier's growing obsession for McKenna, unlike the transient commentator of the earliest pages of the book.

Once Collier reaches 1896, he soon meets McKenna outside Hotel de Coronado. However, his courtship is impeded by McKenna's mother and her manager William Fawcett Robinson, who keep him at arm's length believing him to be an opportunist preying upon their young starlet. Collier perseveres 
against their wishes and McKenna's own reservations, and gradually secures her affections. Yet in the Matheson tradition of pitting hapless protagonists against seemingly insurmountable obstacles, it is a far from painless process, and the author dwells on the agonising awkwardness of their interactions and the wheels and cogs of Collier's mind turning as he grapples with courting a woman from an alien era. These scenes are driven largely by dialogue and Collier's narration of his thought processes. The film closely follows the novel's trajectory of events, albeit with some differences: McKenna's mother is not present; McKenna is more forthcoming in her growing affection for Collier; and dialogue, direction and performance adopt a lighter touch than their angstier source material. Moreover, as the narrative is no longer limited to Collier's point of view, there are additional scenes between McKenna and Robinson (played by Christopher Plummer) which deepen their relationship. These scenes also, along with the aforementioned opening scene, contribute to investing McKenna with greater personal agency, as does an improvised monologue she delivers to Collier during a stage performance.

Earlier I noted the challenge that filmmakers face in translating Matheson's signature everymen characters to film, and this is often due to incongruous casting choices. The three adaptations of Matheson's novel I Am Legend (1954) attest to this, with the everyman timbre of Robert Neville - the lone, neurotic human survivor in a world populated by vampires - repeatedly undermined by characterisation and casting: elder hams (Vincent Price in The Last Man on Earth, 1964), superstars (Will Smith in I Am Legend, 2007), and elder ham superstars (Charlton Heston in The Omega Man, 1971) make for poor everymen. ${ }^{6}$ However, the casting of Christopher Reeve, then fresh from his star-making (and typecasting) role in Superman, works in Somewhere in Time's favour. The role of Collier appealed to Reeve because he was looking for «[...] something very quiet, something very different» to follow Superman (Bouzereau, 2000). Yet the best quality Reeve brings to Collier is the same quality he brought to Superman: his earnestness and sincerity. While Reeve became a star because of Superman, his was not a particularly showy performance, especially compared to co-stars like Gene Hackman, Ned Beatty, and Margot Kidder. Rather, his sincerity anchors that film and it similarly grounds and makes feasible the events of Somewhere in Time. He does not entirely persuade in earlier scenes where he displays apathy, but fares a great deal better depicting

6 Matheson was particularly critical of Price's casting in The Last Man on Earth, believing «Price was totally wrong for it» (qtd. in Bradley, 2010: 122). One can only imagine what sort of Neville Arnold Schwarzenegger would have made in Ridley Scott's mooted film of I Am Legend in the 1990s (265). 
a man in love. Some critics, blinded by his iconic turn as the Man of Steel, were not convinced by his change of direction. Roger Ebert (1980), for instance, felt Reeve was «[...] not particularly convincing in it. He seems a little stolid, a little ungainly.» However, this ungainliness is appropriate to the character. Collier is literally out of time and out of place. As Szwarc (2000) observes, Reeve does not blend easily into the period setting like Christopher Plummer, but rather resembles a «[...] bear in a China shop» in that environment. This highlights his disconnection from the setting, and even affords Reeve, as he later noted, a chance to indulge some of his Clark Kent goofball shtick as he adapts to his new environment (Bradley, 2010: 226).

In his lukewarm review, Ebert (1980) also compared Somewhere in Time unfavourably to Nicholas Meyer's Time After Time (1979), a time travel film about H.G. Wells and Jack the Ripper in modern day San Francisco released the previous year. In particular, Ebert criticised what he perceived as Somewhere in Time's lack of playfulness with its time travel gimmick. I would disagree with Ebert on two counts. Firstly, Somewhere in Time is more closely bound to romance genre conventions than Meyer's headier blend of thriller, romance, comedy and fantasy, and his unfavourable comparison is unfair on that basis. Secondly, the film does indulge in some playfulness, much of it based in comedy of errors. For example, when Collier first awakens in the past, he finds himself in someone else's hotel room in the thick of an argument and must sneak out unnoticed in the tradition of drawing room farce. In addition, the period wardrobe Collier selected in the future turns out to be anachronistic by at least a decade, he cuts his face badly when attempting to shave with a traditional razor for the first time (also a gag in the novel; Matheson, 1980a: 214-215) and his attempts at speaking and acting oldfashioned often miss the mark (and provide plum opportunities for Reeve to indulge in his Clark Kent shtick). As Szwarc (2000) notes, «[w]herever possible, we injected lightness into it» to offset the heavier dramatic content to follow. These scenes exemplify this intent.

Matheson's novel is more concerned with character than the politics and logistics of time travel. He once observed: «Through the years I have been able to get more and more into character, but I never went into stories based on characters. I went into the stories based on a story idea. Then I put characters in the story that I hoped would be believable and realistic» (qtd. in Myers, 2011). This was also the case with Bid Time Return - the idea evolved from seeing a picture of stage actress Maud Adams similar to the picture of McKenna that is central to the story (Bradley, 2010: 220). However, Collier and, to 
a lesser extent, McKenna are the focal points of the novel, just as Scott Carey is The Shrinking Man's focal point and Robert Neville is I Am Legend's. Even so, Matheson devotes some of the book to meditating on the possibilities of time travel. He explores theory related to time travel early in the novel via Collier's research, and later has Collier muse on differences in conduct and culture between eras. For example, a joke is made at the expense of the journalism of the period - «The Wretched Sentenced to Six Years in Prison. There's what I call objective journalism» (Matheson, 1980a: 213) - and elsewhere he ponders where the great figures of the era and near future are currently located:

Einstein is a teenager in Switzerland. Lenin is a young lawyer, his revolutionary days far ahead of him. Franklin Roosevelt is a Groton student, Gandhi a lawyer in Africa, Picasso a youth, Hitler and De Gaulle schoolboys. Queen Victoria still sits on the throne of England. Teddy Roosevelt has yet to charge up San Juan Hill. H.G. Wells has only recently published The Time Machine. McKinley has been elected this very month. Henry James has just fled to Europe. John L. Sullivan is newly retired from the ring. Crane and Dreiser and Norris are, only now, beginning to evolve the realistic school of writing. And, even as I write these words, in Vienna, Gustav Mahler is commencing his duties as conductor of the Royal Opera (Matheson, 1980a: 187-188).

Somewhere in Time likewise concentrates on character but also entertains a number of time travel possibilities, many invented specifically for the screen story. These ideas and plot points are set up in the earlier contemporary-set section of the story and pay off later in the period setting. For example, as mentioned earlier, both McKenna and Collier listen to Rachmaninoff in the present; as the film later reveals, it is Collier who introduces her to this particular melody - his Rhapsody on a Theme of Paganini (Op. 43, Variation XVIII) - in the past when he whistles it during their time together. As also mentioned earlier, the senior McKenna gives Collier a pocket watch in the present. Collier, in turn, takes the pocket watch back through time with him and leaves it in the past, enabling her to give it to him in the future. While the watch is also present in the novel, it is simply a gift from McKenna in the past and is not invested with any thematic or temporal significance. Also invested with greater thematic and temporal significance in the film is McKenna's photograph. The film depicts the taking of this photograph in the past, and Collier is present when it is taken. McKenna looks and smiles directly at him as it is being taken, meaning that when he falls for this image in the future he is falling for a gaze intended specifically for him. Another invention of the film is 
the character Arthur, whom Collier meets in the present as a senior member of the Grand Hotel's staff and encounters in the past as a child. Finally, where in the novel it is a random modern penny which Collier discovers in his clothing that ruptures his connection to the past and propels him back to the present, in the film it is Collier himself who secrets the anachronistic coin in his outfit, which lends the tragedy of their separation a sardonic, self-defeating quality. These setups and payoffs attest to the film's moderate fascination with the story's time travel mechanics.

\section{BACK TO THE FUTURE}

The discussion up until this point has focused on various creative choices made in translating Bid Time Return to film. The rationales behind these decisions - streamlining the narrative, finding cinematic equivalents or alternatives for certain themes and scenes from the novel - are not unique to this specific instance of adaptation. However, they are representative of Matheson's savvy and sophistication as an adapter of source material - whether his own or that of others, such as his adaptations of Edgar Allan Poe for Roger Corman ${ }^{7}$ - and the insights which his dual professions as screenwriter and novelist (as well as short story author) gave him into the strengths and weaknesses of both mediums. In this final section, however, I turn to a fundamental deviation - in narrative, tone and ideology - of Somewhere in Time from its source material, one which marks the film as a critical transformation of its source text and an exemplar of infidelity as an asset in the realms of both adaptation and adaptation discourse.

Of the two texts discussed here, Somewhere in Time is the more conventional romantic drama. Where Bid Time Return's neurotic narration provides the book with an anchor of sorts, Somewhere in Time is a purer cut of romantic melodrama, albeit a cut above a time-travelling Nicholas Sparks weepie. Still, at several points throughout the novel Matheson's neurotic narration gives way to soppier sentiments, notably when Collier and McKenna are reunited following a contrived separation. After spending a day bonding, Collier is abducted during McKenna's stage performance by thugs working for Robinson. He escapes and believes her gone, only for them to be reunited. They proceed to reveal the depths of their feelings for each other, which is where

7 While Corman's popular Poe films were often critically maligned on and after their release (e.g. Gifford, 1973: 190; Hutchinson \& Pickard, 1983: 105), a number are considered classics today and are often included in volumes celebrating the greatest horror films (e.g. Empire, 2000; Schneider, 2009). 
Matheson indulges his syrupy side. This syrupiness is prelude to a devastating blow, and indeed makes the blow all the more devastating when it arrives, yet high reader tolerance is required for prose like «[h]er childlike laughter so delighted me. I thought my heart would burst from happiness» (Matheson, 1980a: 296). Suffice to say, Matheson is better suited to neurotic, sardonic protagonists than love-struck, elated ones.

Even so, amidst these exchanges Matheson tempers the sentiment by subtly foreshadowing the couple's eventual permanent separation, with McKenna repeatedly expressing anxiety that they will be torn apart. Collier and McKenna also consummate their relationship multiple times, which is likewise ominous of events to come, at least for readers familiar with Matheson's work. Though he downplays its significance to his writing (Bradley, 2010: 180), sex is a recurring theme in Matheson's literary work. Earthbound (1982) and Hell House (1971) are notable examples, albeit heavily concerned with sexual monstrosity, and both The Shrinking Man and I Am Legend feature lead characters frustrated by the absence of sex in their lives and the impotence borne by their situations (shrinking in the former's case, lack of companionship in the latter's). While romantic rather than sexual love is the focus of Bid Time Return, Collier's sexual yearnings are hinted at throughout. For example, when he watches McKenna perform barefoot on stage he excitedly thinks «[h] er feet are bare! [...] How can the sight of her feet excite me? I've seen women at beaches, almost naked. Nothing. But those unclothed feet - her feet. It's incredible» (Matheson, 1980a: 249). Yet like those works alluded to above, little good stems from sexual desire or success.

After their night of passionate conversation and lovemaking, Collier has an altercation with Robinson. Following that, the proverbial penny literally drops. Collier discovers the aforementioned anachronism in his suit and is thrust violently back to the present day. As he bitterly muses, «[a] flipped penny had brought me to San Diego in the first place. A penny had taken me to her. A penny had taken me away» (Matheson, 1980a: 312). He laments, «Elise was gone. I had found her but now she was lost. Done. What I had read in those books [about her being heartbroken, growing old and dying alone] was true. Done. None of them would be rewritten now» (311). Indeed, far from being rewritten as he had hoped, what happens according to those history books will transpire precisely because of Collier, his courting of her, and his violent separation from her, investing the tragedy with a cruel irony.

However, Bid Time Return creates ambiguity around whether Collier even returned to the past or not. In regards to narrative logic, two key things 
invalidate Collier's reminiscences. Firstly, as indicated previously the sections of the novel written in the past are longer and more elaborate than those composed in the present; however, it is unfeasible that such lengthy passages could be written in the short spaces of time available to the narrator. Secondly, once in the past the constantly introspective narrator does not at any point contemplate the fact he has a brain tumour and, despite reaching McKenna, will have little time with her. Indeed, at one point he muses «[...] one day, when we have gotten old together, I will tell you how [Mahler's] Ninth Symphony helped bring us together» (Matheson, 1980a: 300). Implicit in this is the possibility that his journey to the past is merely a hallucination or a psychological retreat, a mechanism of escape and denial. This idea is foreshadowed in brother Robert Collier's opening to the manuscript, and further substantiated in his postscript, which elaborates in detail how Collier would have constructed the fantasy of his romance with McKenna. ${ }^{8}$ It is a cold splash of water on the reader, following the cold splash that was Collier's violent return to the present. However, it is ultimately for the reader to decide whether to interpret Collier's journey to the past as delusion or genuine, and in doing so whether they choose to invest in the fantastical or real scenario. Robert himself expresses for his lost brother a kernel of hope that the events of the novel did transpire: «[p]art of me wants very much to believe that it was not a delusion at all. That Richard and Elise were together as he said they were. That, God willing, they are, even now, together somewhere» (316).

In its final scenes, Somewhere in Time speaks to this romantic impulse. The film posits that Collier really does go back in time to see McKenna, is forced violently back to the present, and is reunited with her in the afterlife, with no element of doubt, however obscure, generated. In doing so, the subplot of Collier's brain tumour is completely jettisoned, partly because, as Szwarc has remarked, «[...] on film terminal illnesses do not do well» (Bouzereau, 2000). While the success of Love Story (1970) - a romantic film featuring illness, death and separation, and one of the biggest commercial successes of the previous decade - is at odds with Szwarc's comment, this creative decision was nonetheless consistent with the Hollywood culture of the time, as will be discussed shortly. In light of the film's revised ending, the novel's framework as a manuscript with an opening and postscript by the narrator's brother is also abandoned. While films depicting manuscripts from the dis-

8 Those aforementioned instances of McKenna fearing their separation could also be interpreted, in psychoanalytic terms, as Collier's unconscious mind intruding on his fantasy and warning of its impending collapse. 
tant or recent past being read in the present are common - see, for example, romantic drama The Bridges of Madison County (1995) and fantasy adventure John Carter (2012) to name just two - this device can sometimes minimise the impact and immediacy of the storytelling. It is precisely these qualities - impact and immediacy - which first attracted Matheson to film and television. According to the author, these mediums were attractive «[...] because of their immediacy. I mean there's nothing like reading a good book, but a film hits you right in the face» (qtd. in Bradley, 2010: 4). While Bid Time Return's inherent textuality as an autobiographical record and fantastical construction is central to its meaning, it is not, as the aforementioned popular clichés about cinema noted by Hutcheon (2006: 56-67) suggest, necessarily suited to a medium that thrives on action and exteriority. Moreover, translating the story to film using the novel's framework would have resulted in its events being strictly bound to the perspective and fate of the manuscript's author - hence robbing McKenna of the moments of agency the film provides her - as would its denouement. Instead, Matheson reinvents the novel's denouement in a way better suited to the story's new medium.

In the film, the novel's dialogue-heavy scenes and multiple sexual encounters between Collier and McKenna following their initial separation and reunion are shaved down to one conversation - culminating in his return to the past - and one sexual encounter before it, which is consistent with the economical streamlining of certain events discussed previously. ${ }^{9}$ Their intercourse transpires off-screen, glimpsed only briefly through lacy curtains. Director Szwarc (2000) believed that showing sex between Collier and McKenna would «[...] take away the ethereal quality» of their romance and the «[...] very idealistic view of love» that the film posits. Similarly, Reeve felt «[i]t would have been in very poor taste» to depict their love scene (Bouzereau, 2000). This emphasis on romantic purity is somewhat at odds with Matheson's repeated use of sex as a narrative and thematic trope in his literary work and reinforces that the film is of a tamer, more romantic stock than its source novel. ${ }^{10}$

In Matheson's novel McKenna is asleep when Collier is thrust back to the future, but she is awake and they are conversing when it transpires in the screen story. This choice invests the scene with greater dramatic effect than if

9 To this effect, it also jettisons the novel's altercation between Collier and Robinson.

10 On a side note, the film preceded another science-fiction film about a man who travels through time after falling in love with a woman's photograph: James Cameron's The Terminator (1984). While Szwarc and Cameron's films are wildly different aesthetically, both feature doomed but transcendental romances. 
Collier were alone. Moreover, where in the novel McKenna repeatedly expresses concern that they will be separated, ensuring the spectre of potential loss looms over the narrative, it is not foreshadowed in the film, making their separation all the more abrupt and unsettling. Szwarc's directorial choices make their separation even more dramatic and jarring: the camera adopts Collier's point of view and pulls away from McKenna as she screams his name repeatedly, pulling further and further away until the screen is pitch black. Following his return to the present, Richard attempts to will himself back to the past but is too emotional and exhausted. He loses his reason to live and falls into a catatonic state, and then, as Reeve describes it, «[...] dies of a broken heart» (Bouzereau, 2000).

It is at this point that Somewhere in Time deviates most significantly from its source text. Liberated from the novel's framing device, terminal illness subplot, and narrative ambiguity, the screen story embraces the romantic impulse expressed in Robert Collier's epitaph to his brother in the novel, depicting the lovers' reunion in the afterlife. Like the scene described above, the camera once again adopts a first person perspective, albeit this time of Collier's spirit. The spirit retreats from Collier's lifeless body and moves towards an otherworldly white light, where it is reunited with McKenna to the accompaniment of John Barry's lush musical score. In his commentary Szwarc (2000) describes this sequence as «[...] going into another dimension» (as Scott Carey does in The Shrinking Man), yet the bright whiteness of the set conforms to fairly widespread Christian conceptions of the afterlife.

Somewhere in Time may not be quite as syrupy as Bid Time Return's syrupiest prose, but due to this revised ending it is ultimately more conventionally romantic. In jettisoning Collier's illness and the shadow of doubt it casts over the narrative's credibility, in perpetuating the purity and genuineness of its lovers' romantic union, and in depicting their reunion in a realm unshackled of the parameters of earth and time, the film perpetuates the romantic inclinations that Matheson's novel ultimately and quite deliberately undermines. In light of this fundamental difference between novel and film, it could be argued that the film undermines its source text. However, it is reductive and reactionary to dismiss the ending as a betrayal or cheapening of the source material. Rather, it is far more rewarding to look at these decisions as constituting a transformation of the source text, a re-interpretation of it for a different medium and climate. The film's immediate cinematic context is especially revealing. As mentioned earlier, Somewhere in Time was produced in the wake of fantastical juggernauts like Star Wars, Close Encounters of the Third 
Kind, Star Trek: The Motion Picture, and Superman. Its year of release also marked the release of further colourful franchise-minded spectacles like The Empire Strikes Back (1980), Flash Gordon (1980), and Superman 2 (1980), also headlined by Reeve. ${ }^{11}$ Somewhere in Time is a more muted affair than any of these films - and undoubtedly suffered financially for this - yet with its revised happy ending and elimination of Collier's illness it reflected the growing «[...] process of disengagement and retreat» in American cinema in the aftermath of Star Wars, as noted by Peter Hines (1999: 59). The transition from the politically-minded, auteur-driven American cinema of the 1970s to the lightweight, populist American cinema of the 1980s is an oft-told tale (e.g. Biskind, 1998), and its clichéd seams are evident: as Tom Shone (2004: 9) points out, there were enough populist blockbusters in the early 1970s - like Airport (1970), The Sting (1973), and The Towering Inferno (1974) - to undermine the cliché of the auteur-driven American cinema that abruptly ended with the arrival of Luke Skywalker. Nonetheless, the novel Bid Time Return's ending where Collier is separated from McKenna, dies, and it is revealed his journey through time and romance were merely hallucinatory - would not have been out of place in the early-to-mid 1970s American cinema, given the tragic ending of Love Story or the pessimistic endings of The Godfather Part II (1974), The Parallax View (1974) and Network (1976), to name a few signature films from the era. By 1980, however, this ending would have flown contrary to the reigning cultural and cinematic tide, as studio politics surrounding the endings of Blade Runner (1982) and Brazil (1985) within the next few years would attest. Somewhere in Time's denouement was thus consistent with the Hollywood culture of the time, and it is more rewarding and educational to regard this denouement as an informed re-interpretation reflecting its cultural context than simply as a commercially mercenary betrayal of the source text (which, given the film's disappointing box office, holds little weight).

Tweaking source texts to match the aesthetic strengths of cinema is a storytelling necessity. The utopian notion of a definitive adaptation of a book or short story on screen is naïve and does not take into consideration the subjective thrust of the reading experience. Brian McFarlane (2007: 15) rightly notes that «[...] every reading of a literary text is a highly individual act of cognition and interpretation. " In other words, all readers digest and imagine the same text in different ways, and because an adaptation is ultimately a single reading of a text the idea of an authoritative adaptation of

11 Szwarc, as director of sequel Jaws 2 (1978) and spinoff Supergirl (1984), also contributed to this bombastic franchise culture. 
any work is misguided. As I have discussed at length elsewhere (Kooyman, 2013), the discourse surrounding film adaptations of literary works, both within academia and in the popular consciousness, has long been hampered by the equation of fidelity with successful adaptation and infidelity with unsuccessful adaptation. Thomas Leitch (2008: 64) characterises the field of adaptation studies especially as «[...] still haunted by the notion that adaptations ought to be faithful to their ostensible sourcetexts.» Robert Stam (2005a: 14) advocates for «[...] mov[ing] beyond the moralistic and judgmental ideal of fidelity», while Julie Sanders (2006: 20) suggests that often «[...] at the very point of infidelity... the most creative acts of adaptation» can emerge. To damn film adaptations of literary works for their digressions is reactionary and reductive. To understand and illuminate a film adaptation's digressions in tone, ideology and narrative denouement via reference to its broader cinematic context, and consequently to read an adaptation as a transformation of its source, is far more valuable. Somewhere in Time attests to this. While it is undoubtedly a more conventional romantic drama than Bid Time Return, it also represents a successful adaptation of this source text once fidelity is jettisoned as a criterion for success. The screen story adapts much of the source faithfully, streamlines narrative incident where necessary, and finds cinematic equivalents for aspects of the novel - its interiority of characterisation, its inherent textuality - difficult to translate to screen. More importantly, it critically assesses the suitability of certain aspects of the novel specifically its denouement - for film and opts to re-interpret and transform them. The film thus exemplifies Matheson's savvy as adapter (as well as director Szwarc's) and reinforces that fidelity is not the crux of successful adaptation.

\section{BIBLIOGRAPHY}

BouZEREAU, Laurent (dir.) (2000): «Back to Somewhere in Time», Somewhere in Time, DVD, Universal, U.S.A.

BISKIND, Peter (1998): Easy Riders, Raging Bulls, Bloomsbury, London.

BRAdLey, Matthew R. (2010): Richard Matheson on Screen: A History of the Filmed Works, McFarland, Jefferson NC.

EBERT, Roger (1980): «Somewhere in Time (1980)», Roger Ebert.com, available in <http:/ / www.rogerebert.com/reviews/somewhere-in-time-1980> [10 December 2013].

EMPIRE (2000): Empire: The Greatest Horror Movies Ever, n. ${ }^{\circ}$ 1, Wisecrack Productions. 
Frus, Phyllis \& Christy Williams (2010): «Introduction: Making the Case for Transformation», in Phyllis Frus \& Christy Williams (eds.), Beyond Adaptation: Essays on Radical Transformations of Original Works, McFarland, Jefferson NC, pp. 1-18.

GIFFord, Denis (1973): A Pictorial History of Horror Movies, Hamlyn, London.

Hines, Peter (1999): «The Politics of Disengagement», Independent Filmmakers, November, pp. 58-60.

Hutcheon, Linda (2006): A Theory of Adaptation, Routledge, New York.

Hutchinson, Tom \& Roy Pickard (1983): Horrors: A History of Horror Movies, Wattle Books, London.

KING, Stephen (1981): Danse Macabre, Everest House, New York.

Kooyman, Ben (2013): «The Pedagogical Value of Mary Shelley's Frankenstein in Teaching Adaptation Studies», in Aalya Ahmad \& Sean Moreland (eds.), Fear and Learning: Essays on the Pedagogy of Horror, McFarland, Jefferson NC, pp. 245-263.

LeITCH, Thomas (2008): «Adaptation Studies at a Crossroads», Adaptation, no. 1.1, pp. 63-77.

$<$ http:/ /dx.doi.org/10.1093/adaptation/apm005>

Matheson, Richard (1980a): Somewhere in Time (first pub. Bid Time Return, 1975), Tor, New York.

Matheson, Richard (1980b): Somewhere in Time (Revised Final Draft), available in $<$ http://screenplayexplorer.com/wp-content/scripts/Somewhere_In_Time. pdf $>$ [1 April 2014].

McFarlane, Brian (2007): «Reading Film and Literature», in Deborah Cartmell \& Imelda Whelehan (eds.), The Cambridge Companion to Literature on Screen, Cambridge University Press, Cambridge, pp. 15-28.

<http://dx.doi.org/10.1017/ccol0521849624.002>

MYers, Scott (2011): «How they write a script: Richard Matheson», Go into the story, available in <http:/ /gointothestory.blcklst.com/2011/01/how-they-write-scriptrichard-matheson-html> [10 December 2013].

SANDERS, Julie (2006): Adaptation and Appropriation, Routledge, London. <http:/ /dx.doi.org/10.4324/9780203087633>

SchneIDER, Steven Jay (ed.) (2009): 101 Horror Movies You Must See Before You Die, ABC Books, Sydney.

SHONe, Tom (2004): Blockbuster: How Hollywood Learned to Stop Worrying and Love the Summer, Simon \& Schuster, London.

STAM, Robert (2005a): «Introduction: The Theory and Practice of Adaptation», in Robert Stam \& Alessandra Raengo (eds.), Literature and Film: A Guide to the Theory and Practice of Film Adaptation, Blackwell, Malden, pp. 1-52.

STAм, Robert (2005b): Literature through Film: Realism, Magic, and the Art of Adaptation, Blackwell, Malden.

<http:/ /dx.doi.org/10.5860/choice.42-6390>

SzWARC, Jeannot (dir.) (1981): Somewhere in Time, Universal, U.S.A.

SzWARC, Jeannot (commentary) (2000): Somewhere in Time, DVD, Universal, U.S.A. 